\title{
Plasma Citrulline Concentrations in Neonates and Infants with or without Gastrointestinal Disease and Bowel Resection
}

\author{
Oscar R. Herrera1,2*, Michael C. Storm ${ }^{1,2}$, Richard A. Helms ${ }^{1,2,3}$ \\ ${ }^{1}$ Department of Clinical Pharmacy, University of Tennessee Health Science Center, Memphis, TN, USA \\ ${ }^{2}$ State of Tennessee Center of Excellence in Pediatric Pharmacokinetics and Therapeutics, Memphis, TN, USA \\ ${ }^{3}$ Department of Pediatrics, University of Tennessee Health Science Center, Memphis, TN, USA \\ Email: *oherrera@uthsc.edu
}

How to cite this paper: Herrera, O.R., Storm, M.C. and Helms, R.A. (2016) Plasma Citrulline Concentrations in Neonates and Infants with or without Gastrointestinal Disease and Bowel Resection. Food and Nutrition Sciences, 7, 1063-1069.

http://dx.doi.org/10.4236/fns.2016.712102

Received: March 17, 2016

Accepted: October 11, 2016

Published: October 14, 2016

Copyright $\odot 2016$ by authors and Scientific Research Publishing Inc. This work is licensed under the Creative Commons Attribution International License (CC BY 4.0).

http://creativecommons.org/licenses/by/4.0/ (c) (i) Open Access

\begin{abstract}
Various studies have shown a role for citrulline as a gut mass biomarker in patients with short bowel syndrome. Our hypothesis is that plasma citrulline is both a gastrointestinal (GI) function and a gut mass marker. Our objective was to validate previous observations, by prospectively analyzing plasma citrulline concentrations in patients with GI disease with or without bowel resection, compared to patients without GI disease. Plasma from blood samples of parenteral nutrition fed neonates and infants was obtained. Samples were analyzed by ion-exchange chromatography. Data collected included age, diagnoses and surgical documentation of bowel resection. Patients were classified into 3 main groups: those without GI disease nor resection (Group 1), those with GI disease but no resection (Group 2), and those with GI disease and resection (Group 3). Group medians were compared using KruskalWallis ANOVA. Seventeen samples were evaluated. Patients in Group 3 were older compared to patients in Groups 1 and 2; median age (in days) 156 vs. 12 vs. 57 respectively. Median (range) plasma citrulline concentrations were 20.9 (14.9 - 29.0) $\mu \mathrm{mol} / \mathrm{L}, 8.7(0.5-20.0) \mu \mathrm{mol} / \mathrm{L}$ and $9.6(5.9$ - 13.2) $\mu \mathrm{mol} / \mathrm{L}$ for Groups 1,2 and 3 respectively. There were significant differences among medians and sample distributions between Groups 1 and 2 and between 1 and 3 ( $p<0.05$ ). No differences were observed between Groups 2 and 3. Patients without GI disease and no resection had significantly higher plasma citrulline concentrations than patients with GI disease with or without resection at the time of assessment.
\end{abstract}

\section{Keywords}

Plasma Citrulline, Gastrointestinal Function, Biomarker, Neonates, Infants, Parenteral Nutrition 


\section{Introduction}

Citrulline is a non-essential amino acid synthesized predominantly in the enterocytes [1]. It is not involved in protein synthesis per se, though only as a precursor in the de novo synthesis of arginine [2]. In the early 2000's, the first reports were published of potential clinical uses of citrulline as a marker of gastrointestinal (GI) absorptive function in adults with short bowel syndrome [3]. Preterm neonates, given their immaturity, are particularly at risk of developing necrotizing enterocolitis (NEC) [4] [5]. These infants often require prolonged parenteral nutrition (PN) supplementation due to development of enteral feeding intolerance [6].

Our interest, as well as that of others, has been to evaluate plasma citrulline concentrations in premature infants and correlate those with their intestinal function [7]. Studies have shown that preterms, otherwise healthy, can achieve plasma citrulline concentrations that would be comparable to healthy term neonates [8] and even adults [3]. Recently, Stultz et al. conducted a retrospective analysis of plasma citrulline levels from infants requiring parenteral nutrition (PN), with or without bowel loss. Concentrations were low in both groups initially. However, as enteral feedings were advanced in the no bowel loss group, citrulline concentrations increased compared to the bowel loss group where values often times remained undetectable [9]. Our working hypothesis is that plasma citrulline could be used as both a functional and a gut mass biomarker. The aim of this study was to validate previous results from our institution, by analyzing differences in plasma citrulline concentrations in a cohort of patients with GI disease and variable degrees of bowel resection, compared to patients without GI disease as well as add to the growing body of literature showing plasma citrulline utility as a marker in GI disease.

\section{Methods}

Our study included neonates and infants up to 6 months of age, inpatients at Le Bonheur Children's Hospital (LBCH) in Memphis, TN, who were enrolled in the PN service during their hospital stay and had received intravenous nutrition. All whole-blood samples had been collected as part of routine medical care. The samples were retrieved from the clinical laboratory at $\mathrm{LBCH}$ after routine analysis was completed. Blood samples were chosen based on available volume left, approximately 200 microliters required for chromatographic analysis. Once a sample had been identified for analysis, it was traced back to the patient whom it was extracted from. Data collected included age, diagnoses, surgical documentation of bowel resection if any, feeding regimens, and other notable routine-care laboratory values. They were classified into 3 main groups: patients without GI disease or resection (Group 1), patients with GI disease but no resection (Group 2), and patients with GI disease and resection (Group 3). The study was approved by the University of Tennessee Health Science Center (UTHSC) Institutional Review Board (IRB). The requirement for informed consent was waived by the IRB. Whole-blood was centrifuged and the supernatant was drawn into sampling tubes, discarding the buffy coat and erythrocytes. Plasma was analyzed by ion-exchange chro- 
matography on a Prominence HPLC system (Shimadzu, Houston, TX) using a singlebuffer (lithium citrate), two-temperature program with post-column ortho-phthalaldehyde (OPA) derivatization and fluorescence detection $\left(\lambda_{\mathrm{EXC}}=330 \mathrm{~nm}, \lambda_{\mathrm{EM}}=465\right.$ $\mathrm{nm})$. Data were described as median with ranges, as they were not normally distributed. Nonparametric statistical analyses were used to compare group medians (KruskalWallis ANOVA) performed on SPSS 32-bit software package for Windows (release 22.0.0; IBM Corp.).

\section{Results and Discussion}

We surveyed the clinical laboratory at LBCH daily between February and April 2012, searching for samples from patients that had been enrolled in the PN service. This study was a collection of retrospectively drawn blood samples in which citrulline concentrations were quantified prospectively. The total number of samples analyzed was seventeen, obtained from eleven different patients. Five samples forming Group 1, six in Group 2, and six in Group 3 (see Table 1). Patients in Group 3 were older compared to patients in Groups 1 and 2; median age (in days) 156 vs. 12 vs. 57 respectively. Median (range) plasma citrulline concentrations were 20.9 (14.9 - 29.0) $\mu \mathrm{mol} / \mathrm{L}$ for Group $1,8.7(0.5$ - 20.0) $\mu \mathrm{mol} / \mathrm{L}$ for Group 2, and 9.6 (5.9 - 13.2) $\mu \mathrm{mol} / \mathrm{L}$ for Group 3 (see Figure 1). There were significant differences between Groups 1 and 2 ( $\mathrm{p}=0.026$ ), and between Groups 1 and 3 ( $\mathrm{p}=0.031$ ); but not when comparing between Groups 2 and 3 .

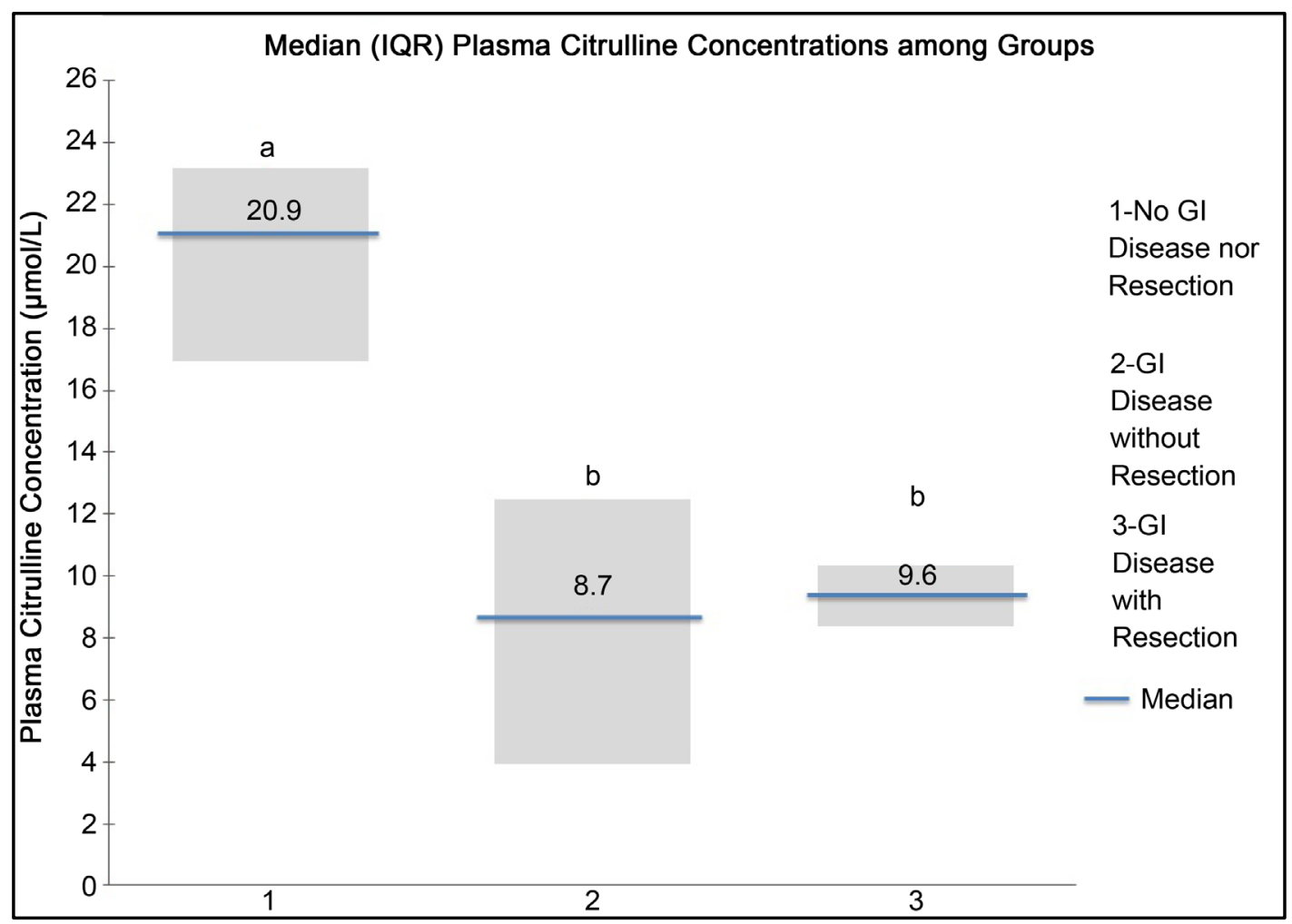

Figure 1. Medians and interquartile ranges of plasma citrulline concentrations within groups. Different letters indicate statistical significancedifference ( $a$ vs. $b, \mathrm{p}<0.05)$. 
Table 1. Patient cohort characteristics.

\begin{tabular}{|c|c|c|c|c|c|c|c|}
\hline Patient & Sample & Age & Diagnoses & $\begin{array}{l}\text { Type of } \\
\text { Surgery }\end{array}$ & $\begin{array}{c}\text { Bowel } \\
\text { Resected } \\
(\mathrm{cm})\end{array}$ & $\begin{array}{l}\text { Feeding } \\
\text { Regimen }\end{array}$ & $\begin{array}{c}\text { Notable } \\
\text { Lab Markers }\end{array}$ \\
\hline A & 1 & 1 week & $\begin{array}{l}\text { Esophageal } \\
\text { Atresia/TEF }\end{array}$ & None & None & NPO & $\begin{array}{l}\text { WBC: } 16.7 ; \\
\text { CRP: } 9.9\end{array}$ \\
\hline B & 1 & 3 months & $\begin{array}{l}\text { Undiagnosed } \\
\text { Congenital } \\
\text { Syndrome }\end{array}$ & None & None & $\begin{array}{l}\text { G-tube feeds } \\
\text { at } 150 \mathrm{~mL} / \mathrm{kg}\end{array}$ & $\begin{array}{l}\text { WBC: } 10.2 ; \\
\text { CRP: } 6.2\end{array}$ \\
\hline $\mathrm{C}$ & 1 & 4 months & $\begin{array}{l}\text { Ventricular/Atrial } \\
\text { Septal Defect }\end{array}$ & Closure & None & $\begin{array}{l}\text { Enteral Feeds } \\
\text { at } 100 \mathrm{~mL} / \mathrm{kg}\end{array}$ & $\begin{array}{l}\text { WBC: } 16.4 ; \\
\text { CRP: } 48\end{array}$ \\
\hline \multirow{2}{*}{$\mathrm{D}$} & 1 & 1 week & $\begin{array}{c}\text { Persistent } \\
\text { Pulmonary } \\
\text { Hypertension/ } \\
\text { ECMO }\end{array}$ & None & None & NPO & WBC: 5.2 \\
\hline & 2 & 2 weeks & $\begin{array}{c}\text { Persistent } \\
\text { Pulmonary } \\
\text { Hypertension/ } \\
\text { ECMO }\end{array}$ & None & None & NPO & WBC: 7.5 \\
\hline E & 1 & 3 days & $\begin{array}{l}\text { Duodenal } \\
\text { Atresia }\end{array}$ & None & None & NPO & $\begin{array}{l}\text { WBC: } 13.4 \text {; } \\
\text { CRP: }<5\end{array}$ \\
\hline \multirow{2}{*}{$\mathrm{F}$} & 1 & 2 months & $\begin{array}{l}\text { Autoimmune } \\
\text { Enteropathy }\end{array}$ & None & None & $\begin{array}{c}\text { Oral feeds } 45 \\
\mathrm{~mL} / \mathrm{kg}\end{array}$ & WBC: 10.6 \\
\hline & 2 & 2 months & $\begin{array}{l}\text { Autoimmune } \\
\text { Enteropathy }\end{array}$ & None & None & $\begin{array}{l}\text { Oral feeds } \\
100 \mathrm{~mL} / \mathrm{kg}\end{array}$ & WBC: 7.3 \\
\hline G & 1 & $\begin{array}{c}4 \\
\text { months }\end{array}$ & MMIHS & None & None & $\begin{array}{c}\text { Enteral feeds } \\
22 \mathrm{~mL} / \mathrm{kg}\end{array}$ & WBC: 9.4 \\
\hline \multirow{2}{*}{$\mathrm{H}$} & 1 & 3 weeks & $\begin{array}{l}\text { Duodenal Atresia/ } \\
\text { Midgut Volvulus }\end{array}$ & $\begin{array}{l}\text { Exploratory } \\
\text { Laparotomy }\end{array}$ & None & NPO & $\begin{array}{l}\text { WBC: } 11.3 \text {; } \\
\text { CRP: } 19.8\end{array}$ \\
\hline & 2 & 1 month & $\begin{array}{l}\text { Duodenal Atresia/ } \\
\text { Midgut Volvulus }\end{array}$ & $\begin{array}{l}\text { Exploratory } \\
\text { Laparotomy }\end{array}$ & None & NPO & $\begin{array}{l}\text { WBC: } 14.7 \text {; } \\
\text { CRP: } 8\end{array}$ \\
\hline \multirow{4}{*}{ I } & 1 & 4 months & $\begin{array}{l}\text { Necrotizing } \\
\text { Enterocolitis }\end{array}$ & $\begin{array}{l}\text { Ex-lap, lysis of } \\
\text { adhesions, } \\
\text { end-to-end } \\
\text { anastomosis }\end{array}$ & $\begin{array}{c}45 \mathrm{~cm} \\
\text { jejunum }\end{array}$ & NPO & WBC: 29.4 \\
\hline & 2 & 5 months & $\begin{array}{l}\text { Necrotizing } \\
\text { Enterocolitis }\end{array}$ & $\begin{array}{l}\text { Ex-lap, lysis of } \\
\text { adhesions, } \\
\text { end-to-end } \\
\text { anastomosis }\end{array}$ & $\begin{array}{c}45 \mathrm{~cm} \\
\text { jejunum }\end{array}$ & NPO & WBC: 39.1 \\
\hline & 3 & 5 months & $\begin{array}{l}\text { Necrotizing } \\
\text { Enterocolitis }\end{array}$ & $\begin{array}{l}\text { Ex-lap, lysis of } \\
\text { adhesions, } \\
\text { end-to-end } \\
\text { anastomosis }\end{array}$ & $\begin{array}{c}45 \mathrm{~cm} \\
\text { jejunum }\end{array}$ & NPO & WBC: 31.8 \\
\hline & 4 & 5 months & $\begin{array}{l}\text { Necrotizing } \\
\text { Enterocolitis }\end{array}$ & $\begin{array}{l}\text { Ex-lap with } \\
\text { lysis of } \\
\text { adhesions, } \\
\text { end-to-end } \\
\text { anastomosis }\end{array}$ & $\begin{array}{c}45 \mathrm{~cm} \\
\text { jejunum }\end{array}$ & $\begin{array}{l}\text { Tube feeds } \\
6 \mathrm{~mL} / \mathrm{kg}\end{array}$ & WBC: 16.3 \\
\hline
\end{tabular}


Continued

\begin{tabular}{ccccccc}
\hline J & 1 & 4 months & $\begin{array}{c}\text { Necrotizing } \\
\text { Enterocolitis }\end{array}$ & $\begin{array}{c}\text { Ex-lap, end-/ } \\
\text { loop-jejunosto } \\
\text { my and } \\
\text { mucous fistula }\end{array}$ \\
jejunum & NPO & NA \\
K & 1 & 6 months & $\begin{array}{c}\text { Necrotizing } \\
\text { Enterocolitis }\end{array}$ & $\begin{array}{c}\text { Ex-lap, cecal } \\
\text { stricturoplasty, } \\
\text { anastomosis }\end{array}$ & NPO & WBC: 19.9
\end{tabular}

Tracheo-esophageal fistula (TEF), White blood cell count in $\times 10^{3} / \mu \mathrm{L}$ (WBC), C-reactive protein in $\mathrm{mg} / \mathrm{L}$ (CRP), nil per os (NPO), Extra-corporeal membrane oxygenation (ECMO), Megacystic Microcolon Intestinal Hypoperistalsis Syndrome (MMIHS), Not available (NA).

Our results suggest that patients without GI disease had significantly increased concentrations of citrulline in plasma compared to patients with GI disease, both with and without resection, as expected. The values in Group 1, which served as our control, are consistent with those reported in previous studies for premature infants [7] [8]. The same variations observed in plasma citrulline concentrations in GI disease among patient groups confirm the results of the retrospective analysis done previously at our institution [9]. If plasma citrulline would be regarded as a simple gut mass marker then we may have expected higher concentrations for those patients from Group 2 compared to Group 3, and quite possibly closer to levels in patients from Group 1. Instead, it was observed that plasma concentrations were similar between the two GI-disease groups and the group median was actually lower in those without resection. This may suggest that Group 2 patients were experiencing ongoing disease, and we suspect ongoing inflammation as well.

There are limitations to this investigation that warrant further discussion. There was considerable variability in plasma citrulline, particularly in Group 2. This could be attributed to inherent analytical limitations from chromatography or ongoing intestinal disease. The assay is based on separation of citrulline from other plasma amino acids by ion-exchange chromatography as used in many studies by other research groups. The lowest concentration measurable from Stultz et al. was $4.2 \mu \mathrm{mol} / \mathrm{L}$ [9], using absorption detection. For this project, we improved the sensitivity of the analysis by using postcolumn derivatization with OPA and fluorescence detection. This considerably improved our lower limit of quantification to $0.5 \mu \mathrm{mol} / \mathrm{L}$. Newer analytical methods for citrulline have been published, using liquid chromatography coupled with mass spectrometry, showing comparable sensitivity [10].

A few patients were receiving enteral feedings at the time the blood samples were collected. Though, secondary analyses revealed no significant difference in plasma citrulline concentrations when the cohort was divided as enterally fed or unfed. Sample size would have played a role as this was conditioned by our minimum volume requirement.

The most significant limitation, perhaps, is the use of one-time measurement of plasma citrulline in these patients. Gastrointestinal function is a dynamic process. In order to be described with any reliability, it would require having multiple assessments 
in order to understand any clinically-significant changes. With this study we improved upon two aspects of the previous investigation: first to prospectively analyze plasma citrulline concentrations from blood samples collected as part of routine patient care, and secondly, use enhanced analytical technology to improve sensitivity. If further validated, these findings would be clinically relevant for practitioners who could use it to better assess gastrointestinal function in patients and manage their transition from parenteral to oral/enteral feedings more appropriately.

\section{Conclusion}

Patients without GI disease had significantly higher plasma citrulline concentrations than patients with GI disease regardless of bowel resection. Evaluating plasma citrulline concentrations longitudinally in these same 3 categories of patients, during both a period of predominant parenteral nutrition and subsequent transition to enteral nutrition is critical to explore the potential use of citrulline as a surrogate marker of both gut mass and function.

\section{Acknowledgements}

The authors received financial support from the Children's Foundation Research Institute and Le Bonheur Children's Hospital (Acct\# 65-0508), and the Center for Pediatric Pharmacokinetics and Therapeutics (CPPT).

\section{References}

[1] Windmueller, H.G. and Spaeth, A.E. (1981) Source and Fate of Circulating Citrulline. The American Journal of Physiology, 241, E473-E480.

[2] Rabier, D. and Kamoun, P. (1995) Metabolism of Citrulline in Man. Amino Acids, 9, 299316. http://dx.doi.org/10.1007/BF00807268

[3] Crenn, P., Coudray-Lucas, C., Thuillier, F., Cynober, L. and Messing, B. (2000) Postabsorptive Plasma Citrulline Concentration Is a Marker of Absorptive Enterocyte Mass and Intestinal Failure in Humans. Gastroenterology, 119, 1496-1505. http://dx.doi.org/10.1053/gast.2000.20227

[4] Morgan, J.A., Young, L. and McGuire, W. (2011) Pathogenesis and Prevention of Necrotizing Enterocolitis. Current Opinion in Infectious Diseases, 24, 183-189. http://dx.doi.org/10.1097/QCO.0b013e328345d5b5

[5] Gosche, J.R., Vick, L., Boulanger, S.C. and Islam, S. (2006) Midgut Abnormalities. The Surgical Clinics of North America, 86, 285-299. http://dx.doi.org/10.1016/j.suc.2005.12.014

[6] Rhoads, J.M., Plunkett, E., Galanko, J., Lichtman, S., Taylor, L., Maynor, A., et al. (2005) Serum Citrulline Levels Correlate with Enteral Tolerance and Bowel Length in Infants with Short Bowel Syndrome. The Journal of Pediatrics, 146, 542-547. http://dx.doi.org/10.1016/j.jpeds.2004.12.027

[7] Ioannou, H.P., Diamanti, E., Piretzi, K., Drossou-Agakidou, V. and Augoustides-Savvopoulou, P. (2012) Plasma Citrulline Levels in Preterm Neonates with Necrotizing Enterocolitis. Early Human Development, 88, 563-566. http://dx.doi.org/10.1016/j.earlhumdev.2011.11.008

[8] Celik, I.H., Demirel, G., Canpolat, F.E. and Dilmen, U. (2013) Reduced Plasma Citrulline 
Levels in Low Birth Weight Infants with Necrotizing Enterocolitis. Journal of Clinical Laboratory Analysis, 27, 328-332. http://dx.doi.org/10.1002/jcla.21607

[9] Stultz, J.S., Tillman, E.M. and Helms, R.A. (2011) Plasma Citrulline Concentration as a Biomarker for Bowel Loss and Adaptation in Hospitalized Pediatric Patients Requiring Parenteral Nutrition. Nutrition in Clinical Practice: Official Publication of the American Society for Parenteral and Enteral Nutrition, 26, 681-687. http://dx.doi.org/10.1177/0884533611425682

[10] Shin, S., Fung, S.M., Mohan, S. and Fung, H.L. (2011) Simultaneous Bioanalysis of L-Arginine, L-Citrulline, and Dimethylarginines by LC-MS/MS. Journal of Chromatography B, Analytical Technologies in the Biomedical and Life Sciences, 879, 467-474. http://dx.doi.org/10.1016/j.jchromb.2011.01.006

Submit or recommend next manuscript to SCIRP and we will provide best service for you:

Accepting pre-submission inquiries through Email, Facebook, LinkedIn, Twitter, etc. A wide selection of journals (inclusive of 9 subjects, more than 200 journals)

Providing 24-hour high-quality service

User-friendly online submission system

Fair and swift peer-review system

Efficient typesetting and proofreading procedure

Display of the result of downloads and visits, as well as the number of cited articles Maximum dissemination of your research work

Submit your manuscript at: http://papersubmission.scirp.org/

Or contact fns@scirp.org 